\title{
Paideusis
}

\section{Imagination and Imaginative: A Trial Separation for Educational Practice}

\section{Mark Frein}

Volume 11, Number 2, 1998

URI: https://id.erudit.org/iderudit/1073104ar

DOI: https://doi.org/10.7202/1073104ar

See table of contents

Publisher(s)

Canadian Philosophy of Education Society

ISSN

0838-4517 (print)

1916-0348 (digital)

Explore this journal

Cite this article

Frein, M. (1998). Imagination and Imaginative: A Trial Separation for

Educational Practice. Paideusis, 11(2), 39-54. https://doi.org/10.7202/1073104ar

(c) Mark Frein, 1998

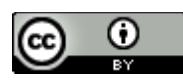

This document is protected by copyright law. Use of the services of Erudit (including reproduction) is subject to its terms and conditions, which can be viewed online.

https://apropos.erudit.org/en/users/policy-on-use/ 


\title{
Imagination and Imaginative: A Trial Separation for Educational Practice
}

\author{
Mark Frein, University of British Columbia
}

\author{
Imagination, which, in truth, \\ Is but another name for absolute power \\ And clearest insight, amplitude of mind, \\ And Reason in her most exalted mode \\ William Wordsworth, The Prelude
}

It is safe to say that the importance of the concept of imagination in philosophy of mind has waned since Wordsworth wrote these lines, although a flip across various young children's television programs shows the continued significance of the concept in everyday educational discourse. ${ }^{1}$ Modern psychological and sociological models have largely replaced the faculty psychology of Romantic and pre-Romantic thinkers. Yet, prominent education theorists continue to press the issue. ${ }^{2}$ In general, those educators who are concerned about imagination (or the lack of it) in schools are advocates of some form of liberal education, though they may diverge on the particulars of a good liberal education. The question of the imagination is not simply a practical question for education. It is a moral one. An "uneducated imagination" is not only a mind full of mush but a mind which may not be able to distinguish between fact and fiction, or right and wrong.

My argument recognizes the importance of these concerns, but offers a practical solution to a practical problem. The practical problem is the education of the imagination. The practical solution involves replacing in educational discourse conceptions of the imagination with talk about what kinds of imaginative work should be encouraged in the classroom. The distinction between "imagination" and the "imaginative" may seem, at first glance, to be only that between a noun and an adjective. I shall argue, however, that our preoccupation with the noun and continued reliance on Romantic conceptions of the imagination and its development blur, or overlook, important differences between the two words and offer little secure practical footing for educators. An understanding of the "imaginative" as the value of convention-testing work within a practice will, I think, provide a much less slippery conceptual footing on which to base educational efforts.

\section{A Relationship Gone Sour}

We can isolate a few features of the Romantic conception of the imagination, though we must realize that two levels of generalization are at hand-one concerning Romanticism, the other the Romantic imagination. ${ }^{3}$ The faculty of the imagination was, for many Romantic thinkers, all-important in the capacity to reason, perceive, feel, and create. Combining elements from philosophers Hume, Kant, and the British associationists, poets William Wordsworth and Samuel Taylor Coleridge held imagination aloft as the noblest part of the mind. ${ }^{4}$ 
The imagination involved that power crucial to the artist or poet: the power to resonate in sympathy not only with other human beings but with the beauty of the natural world. It is the imagination that organizes perception into meaningful wholes and which allows the poet to imbue words with the power to move others. Coleridge wrote:

The Imagination then, I consider either as primary, or secondary. The primary imagination I hold to be the living power and prime agent of all human perception, and as a repetition in the finite mind of the eternal act of creation in the infinite I AM. The secondary I consider as an echo of the former, $\infty$-existing with the conscious will .... It dissolves, diffuses, dissipates, in order to re-create. 5

With these theoretical musings, Coleridge was attempting to wed a century of British and German philosophical work on the imagination for his own critical ends. ${ }^{6}$ From Immanuel Kant-who, in turn, followed David Hume-Coleridge took the notion that some capacity in the mind had to be responsible for our ability to see whole, continuous images from the assumed jumble of sensory impressions. Imagination was, in this sense, the faculty that formed visual images-both from what was seen and from what was pictured in one's mind's eye. From British associationists Adam Smith and William Hazlitt (among others), Coleridge imported the sense that it was imagination which provided the fuel for empathy. The conscious, or creative, act of imagination (Coleridge's "'secondary imagination") unites these two receptive capacities to produce painting, music, and poetry.

While Coleridge's vision of the imagination may continue to be attractive to some artists, musicians, and poets, "faculty" language does not hold water among many modern thinkers. ${ }^{7}$ As education philosopher Robin Barrow points out, analytic philosophy has been cured of faculty language since Gilbert Ryle's famous The Concept of Mind. ${ }^{8}$ Barrow writes, "[Ryle] maintained that intelligence, creativity, imagination, and so forth were not in any way the names of entities, but abstract nouns dependent on the adverbial labels we apply to people insofar as they perform various mental acts in a certain kind of way." "We say a person is intelligent because that person demonstrates "intelligence". through intelligent words or actions. The same is true for imagination. We cannot treat the imagination as the "mind's eye" because we have no actual inner eye. We cannot treat the imagination as muscle because it is not a muscle.

Consequently, the Romantic position that imagination is involved in all perception, both "internal" and "external" becomes very suspect given Ryle's investigations. Imagining a canary and seeing a canary may seem to be similar, but in the case of imagining nothing is actually seen and there is nothing that can be seen. Ryle wrote about imagined noise: "When I fancy I am hearing a very loud noise 1 am not having a mild auditory sensation, as I am not having an auditory sensation at all, though $I$ am fancying that $I$ am having an intense one." 10 With his observations on the nature of mental concepts, Ryle effectively separated imagined sensation from real sensation, thus doing severe damage to the Enlightenment and Romantic accounts of mind. Though we do, indeed, imagine, visualize, and picture, these are appropriately conceived as ways of thinking rather than ways of experiencing "inner" sensation.

I am less confident, however, than Barrow that Ryle's arguments close the book on the confusion about the imagination. For while analytic philosophy 
may have settled the issue forty years ago, the concept of the imagination lives on. Though Ryle is clearly right about the ghostly nature of the meaning of mental concepts, the concept of imagination itself has a concrete and established history. To use the word imagination is usually to at least imply some of the Romantic connotations since, as literary historian James Engell argues, the concept, born from Enlightenment thinkers, was raised by the Romantics. 11 Definitions 3-5 of the Oxford English Dictionary include reference to "power" or "faculty" though we certainly cannot assume that this tells us much about the way the word is commonly used in either ordinary language or education talk. Educators, however, continue to use the word, and it very difficult to discard the Romantic baggage that accompanies it. Warnock writes:

The expression 'power in the mind' may quite properly be found objectionable. It is very hard to find a substitute for the vocabulary of faculty psychology. It seems to me in fact that such vocabulary is steadily becoming more innocuous as we more and more clearly recognize it as metaphorical. ${ }^{12}$

Warnock cannot find a substitute for "faculty" language because, like many other educators, she is committed to preserving a Romantic or pre-Romantic version of the concept of imagination. Indeed, Warnock rather unabashedly recognizes and affirms the Romantic conception of imagination. ${ }^{13}$

This kind of romanticization is theoretically infectious. Philosopher of education Maxine Greene, working from Warnock, writes: "It is my conviction that informed engagements with the several arts would be the most likely way to release the imaginative capacity and give it play." 14 In a time when the arts are subject to a little pinch-if not a big squeeze-in most public schools, the importance of the imagination serves as an effective call-to-arms. Yet, the concept of imagination is strained to breaking by the quasi-metaphorical use to which it is often put. If we are to recognize, as Warnock recommends, the metaphorical nature of the concept, must we not have some idea of what is signified? For what does the metaphor of the "imaginative capacity" in Greene's exhortation about the arts stand? How do we recognize it? How do we educate it and how do we know that we have successfully educated it?

These last two questions bring to the fore the practical dilemma involved in educating the imagination. Though modern thinkers may take issue with the conceptual or scientific fuzziness of a Romantic conception of imagination, the problem changes its nature when it is brought into the classroom. There the words "imagination" and "imaginative" begin to knock heads. When we educate, we do and say things with the hope at the very least that our students will also do and say things better than before. The word "better" may be replaced with numerous other words-more thoroughly, meaningfully, critically, comprehensively, and so on, but all are normative terms. We may not always succeed and we may not always agree on whether or not an education program does, indeed, help students do or say things better, but the intention is still there. Thus, educators concerned about the imagination usually recommend ways to improve or sophisticate the capacity. We do have the term "imaginative," but to use "imagination" and "imaginative" together is much like having too many cooks in the kitchen. The two concepts tend to stumble into each other and become seriously tangled. In particular, the route to the imaginative has been problematically paved through the concept of the imagination. 
For example, there is a tendency to sing praise to imagination or "Reason in her most exalted mode" with Romantic devotion-to assume that the stimulation and development of the imagination is unconditionally a desirable thing. Mary Warnock writes: "Being more imaginative, is, I believe, like being more healthy." 15 It is a position shared and even invoked by other educators and educational theorists, especially in the area of early childhood education. ${ }^{16}$ Yet, obviously, we want students to be imaginative in certain areas and not others. Education philosopher Karen Hanson, criticizing Mary Warnock's celebration of the imagination, writes:

It is not at all obvious that "being more imaginative is . . . like being more healthy'; indeed, if the analogy is as appropriate as Warnock believes it to be, then the idea of an 'excessive imagination' should strike us as impossible and the phrase 'a morbid imagination' should seem to us oxymoronic. But the fact is that these notions are not self-contradictory, and this fact should alert us to the possibility that being more imaginative is not in itself always and necessarily good or desirable. ${ }^{17}$

The argument between Warnock and Hanson is illustrative of the problem. In one very important sense, Warnock is right to draw a parallel between "imaginative" and "healthy": both are terms with positive value connotations. Hanson is also importantly right, however, to point out the fact that we do use phrases such as "morbid imagination." The conflict here, I believe, stems directly from the overlap between a word of value (imaginative) and a word which has been thought to stand for some generalizable part of, or capacity within, the mind. Notice that Hanson attacks Warnock's generalization on linguistic grounds of the "imagination" and not the imaginative.

Equally, there is a danger in assuming that educators want to stimulate students' imaginations. Egan, in the first line of the Introduction to his Imagination in Teaching and Learning, writes: "It seems generally agreed that imagination is a good thing and that it ought to be stimulated and developed in education."18 I do not think we can accept Egan's unsubstantiated generalization as readily as he would have us do. It is just as plausible to believe that many feel, as did Thomas Aquinas and Descartes, that imagination is an enemy to reason and good common sense. If associated with daydreaming, rebelliousness, and other vices, imagination may be seen as a serious obstacle to a good education.

It may be, in general, more desirable to be imaginative than unimaginative; this fact, however, does not give us good reason to unconditionally develop the imagination in education (assuming it could be done). An imaginative student is only a good student insofar as his or her imagination is displayed in the appropriate ways. Simply asking a student to use his or her imagination does not guarantee that what the student comes up with will be imaginative, or even acceptable. Rather, it is the nature and quality of the results that makes the act more or less imaginative.

For example, we may think that we develop students' imaginations when we ask them to work on a castle-building project, paint with watercolours, or write poems (tasks that certainly correspond with a Romantic understanding of imagination). A student asked to do any of these things, however, may or may not produce something that we would call imaginative and probably should not always be expected to do so. 
The relationship between the concepts of imagination and imaginative also, I think, leads educators to make the unfortunate assumption that "being imaginative" is something that people carry around with them like a good haircut. To have displayed imagination is often assumed to make one, in general, an imaginative person. This assumption loses sight of the fact that to be an imaginative scientist, for example, depends on how well one does science. One's talent or skill in science does not necessarily transfer to mechanics or to tennis and one's status as an imaginative scientist does not guarantee equal status as an imaginative mechanic or tennis player. Although we often describe someone as an imaginative person, we do so with contexts in mind.

The word often slips into the role of the equally ambiguous and problematic educational term "gifted." As is the case with "gifted" people, "imaginative" people are sometimes thought to carry around their ability like a third eye. As is also the case with terms like gifted, however, to use imaginative in this way is to make the concept essentially meaningless. In what is a gifted person gifted? In darts? In carpentry?

Egan writes, for example, that "To be imaginative . . . is not to have a particular function highly developed, but it is to have heightened capacity in all mental functions." 19 "Besides the difficulty in understanding what is involved in heightened mental "capacity," we have another problem here: to be imaginative has nothing to do with any functions whatsoever. To be imaginative is to have what one does or says evaluated in a particular, positive way. The word imaginative, when applied to a person, refers to what someone has done or demonstrated. We can compare it to a description of a well-hit baseball as a "good hit." In both cases, the words refer to the result of some action, or set of actions, even if (in the case of "imaginative") those actions are not specifically mentioned. We cannot, for instance, practice "good hits" although we can practice good swings. Likewise, we cannot practice being imaginative although we can practice doing mathematics, writing poetry, painting with watercolours, and so on.

The central problem that ties together all the instabilities between the imagination and the imaginative is a causal link between the use of the two words. If we can more or less give up the imagination as a meaningful educational concept we can free ourselves from the linguistic trap that is our Romantic inheritance but also free ourselves to reaffirm what is at stake in imaginative thought and action.

\section{Making a Clean Break}

The educational problems and confusions that arise from the Romantic conception of imagination sprout from the troublesome link between the concept of the "imagination" and the normative term "imaginative." The concept of the imagination is in everyday talk usually associated with the ability or capacity to form an image in one's mind but we cannot isolate this as the imagination. Consider the example of someone being asked to "imagine how you would feel if . . " or "imagine what it would be like to be rich." 20 Though the process by which we answer these questions may involve forming an image, it need not. As Egan points out, following Jean-Paul Sartre, the invocation of the imagination often carries an emotional response. ${ }^{21}$ Like memories, mind-conjured images can effect us emotionally as if real and present. But, again, the affective 
component is neither a necessary or sufficient condition (for example, "imagine a circle").

The peculiar difficulty involved in conceptualizing the imagination stems from the Romantic history of the concept. How are we to reconceptualize something in modern philosophical terms that is imbued with the Romantic and pre-Romantic "faculty-ism" noted in the previous section? The first move, I believe, is to concentrate on what we are asked to do when asked to "use our imagination." To imagine is to think, feel, or act in certain ways, or, confined by certain rules or expectations. These expectations may vary depending on how we are asked to use our imagination. Typically, when asked to use our imagination, we are expected to deal with possibility. ${ }^{22}$ This conception relies on an understanding of what a person is aiming at, or intending to do or accomplish when he or she is asked to "imagine" and not what capacity, power, or faculty that person employs. To imagine is like "to think" or "to believe." We do not use any particular part of our mind to think or to believe. ${ }^{23}$ Neither do we use a particular part of our mind to imagine.

To speak of the imagination or the imaginative realm as a rough category of ideas, motivations, visions, wants, feelings, and desires, on the other hand, seems perfectly sensible. This not only assumes and recognizes the figurative and sometimes poetic nature of talk about the imagination, but also brings the imagination out of the mind and, thus, relieves the tension between literal and metaphorical use. In his famous radio lecture series, literary critic Northrop Frye, speaking about the importance of the imagination, commented:

What the responsible citizen really uses is his imagination, not believing anybody literally, but voting for the man or party that corresponds most closely, or least remotely, to his vision of the society he wants to live in. The fundamental job of the imagination in ordinary life, then, is to produce, out of the society we have to live in, a vision of the society we want to live in. ${ }^{24}$

One could probably substitute a phrase such as "critical mind" for both instances of the word imagination in this quotation. I would suggest that an even more illuminating substitution would be "education" for imagination. In using his or her imagination, Frye's responsible citizen clearly does not literally use a portion of her mind but draws upon a myriad of traits, habits, dispositions, skills, practices, and kinds of knowledge. Educating the imagination in this case is essentially the same thing as educating the person. Conceptions of imagination usually slide into conceptions of mind in general for there is no instance in which we can remove the typical characteristics of the imagination and still have human intelligence (the ability to speculate, to question, to believe, and so on). To say that we ought to stimulate and educate the mind is to say nothing very interesting or practically useful for educators. Furthermore, if proponents of the imagination respond that they are only using the concept to indicate a certain vague category of ideas, habits, and so on (those dealing with possibility or speculation), they cannot maintain arguments that using, stimulating, or developing the imagination has any concrete connection with perception, memory, emotion, or any other mental capacity.

We are doomed to running on a treadmill as long as we invest time and energy in training and educating the imagination. We are so doomed because, in part, as the imagination has been theoretically conceived, there is no way to tell 
whether or not our educational efforts have worked. There are objective measurements of the strength of our arms or legs but no such measurements of the "work" of the imagination, and for good reason. How can we see a growing, healthy, strong, or capable imagination apart from imaginative words or actions? It would be ridiculous, as we have seen before, to guarantee that any particular educational program or curriculum aimed at stimulating the imagination will produce more imaginative people. Instead of looking to see if the imagination was stimulated or used, we must turn to standards for imaginative work since the imaginative, unlike the imagination, is a normative concept. Barrow writes:

The claim that Smith has imagination or that Jones is imaginative is usually an instance of praise, and clearly refers to the superior quality of the abstract representation engaged in by Smith or Jones. The crucial question is in virtue of what do we regard some people as more imaginative than others in this normative sense? What criteria must my attempts to conceive of what is not immediately present meet, to allow me to earn the honorific label "imaginative.",25

The questions we need, as educators, to ask each other and ourselves include: What are the criteria for imaginative work? What do we, as educators and citizens, value in imaginative work? How do we create a school environment which allows for and encourages imaginative work? Shifting the educational focus from the imagination (and its development and exercise) to the imaginative (and its criteria) may not lead to a reinvigoration of the curriculum. In fact, this change of focus may serve to further alienate those educators who value the imagination. It may further alienate because it understands the relevant questions to be value questions rather than empirical ones. It is a relatively safe move for Egan to ground his work on the assumption that imagination is a "good thing and that it ought to be stimulated and developed in education." It would not be so easy for Egan, or any other proponent of imagination, to ground their work in the claim that the imaginative ought to be stimulated. This claim would beg some obvious questions: What counts as imaginative? Who decides what counts as imaginative?

An educator can be a proponent of imagination without necessarily taking stands on all school practices or all curricular issues. To take a stand on the imaginative, however, is to draw fighting lines about what will count as valuable student work. ${ }^{26}$

\section{Defining the Imaginative}

Rather than look to uncover the essence of the imaginative (which would effectively be to slip off the post-Romantic horse just when we have saddled up), I shall argue that we, as educators, should look toward two things. First, we should look at the standards for imaginative activity and determine to what kinds of activity those standards are usually applied - both to see where the imaginative lies, so to speak, but also to see where we might push the boundaries of imaginative activity and work. Second, we should look at what kinds of contexts, preparation, and experiences help students strive toward those standards.

The influence of the Romantic legacy in talk about the imagination or the imaginative colours the imaginative in certain ways. It skews the realms of the 
imaginative toward the fantastical. "Imaginative" literature is usually fiction, often science-fiction or fantasy. We are more likely to hear a story about dragons or monsters described as imaginative than one about the life of Martin Luther King, Jr. In fact, it may even be taken as an insult by some to have works of non-fiction described as imaginative. The same, I think, applies to artistic representation. Asked to use imagination, students (based on previous experience with the concept) will tend to draw fantastical pictures. Realistic portraits, however, may not be so easily called imaginative.

These distinctions, however, are not hard and fast and are more a result of the expectations under which we work when asked, particularly in artistic contexts, to use our imaginations. There does not seem to me to be any good reason to restrict the praise of "imaginative" to that-which-is-most-unreal. The standards of imaginative work can make equal sense when applied to photo-realistic portraits as to non-representational expressionism in art.

When it comes to standards, imaginative is a very peculiar concept of value. I think we tend to say something or someone is imaginative or has shown imagination when standards are exceeded in hard-to-qualify ways. That is to say, the word "imaginative" applies to standard-breaking or conventionbreaking work. This does not always mean that the imaginative is the pinnacle of achievement. An imaginative poem may break from poetic convention but not be described as a great poem by critics, other poets, or even the author herself.

What I wish to offer as a general understanding of the imaginative is this notion of convention-breaking achievement in a practice or context. To help develop this understanding, I shall turn to two philosophical sources-one on the concept of a practice and one on the concept of style.

Philosopher Alisdair MacIntyre in his highly-acclaimed and much debated After Virtue told his own story about the disintegration and fragmentation of moral systems in the modern world. Part of Macintyre's path out of the moral morass reaches back to Aristotle, and Aristotle's account of virtue. Drawing on this source, Macintyre proposes that virtue be thought of as a fully learnable excellence which allows one to realize the good of a particular activity-a practice. ${ }^{27}$ Macintyre argues that realizing the "goods" internal to a practice such as chess depends upon the practitioner seeing the value of playing chess not for external reward (Macintyre provides the example of paying a young child in candy to play chess) but for the enjoyment of strategy, competition, concentration, and so on.

We need not accept MacIntyre's communitarian ethics-the extension of his understanding of virtue in the moral realm-to make use of his neoAristotelian account of practices. His understanding of "practice" (I think "craft" is a also good word), however, is very useful for investigating educational endeavours. By practice, MacIntyre means:

any coherent and complex form of socially established co-operative human activity through which goods internal to that form of activity are realized in the course of trying to achieve those standards of excellence which are appropriate to, and partially definitive of, that form of activity, with the result that human powers to achieve excellence, and human conceptions of the ends and goods involved, are systematically extended. Tic-tac-toe is not an example of a practice in this sense, nor is throwing a football with skill; but the game of football is, and so is chess. ${ }^{28}$ 
Macintyre also includes the academic disciplines in the notion of a practice as well as artistic and technical "fields" of expression and inquiry.

The relationship of the practitioner to the practice is very important. For MacIntyre, to learn within the practice and to realize the goods internal to the practice, one must submit oneself to its standards of excellence. A practitioner enters a history when entering a practice - "to enter into a practice is to enter into a relationship not only with its contemporary practitioners, but also with those who have extended the reach of the practice to its present point.",

There are a number of good examples of the importance of history in practices. Baseball is full of illustrative potential. MacIntyre writes: "If, on starting to play baseball, I do not accept that others know better than I when to throw a fast ball and when not, I will never learn to appreciate good pitching let alone to pitch."2 Good baseball players are learning baseball players. It is very difficult to learn baseball, or anything, without accepting, to some degree, the authority of others within that practice and the standards of excellence generated
by its history.

"To some degree" is an important caveat and one that I believe MacIntyre does not emphasize enough. When we enter into a practice, we should accept that our judgment concerning its standards is in need of cultivation and improvement. We should also, however, be encouraged to see that there has always been and will always be room for experimentation and innovation within the practice-innovation which, to use MacIntyre's words, "extends" the standards within the practice itself. That is to say, we should be encouraged to be
imaginative.

The imaginative is that which extends practices, contexts for human action which have histories of excellence and achievement. "Extends" should not be taken as the same as progress, however. Whether or not the atonal musical arrangements of the 20th century are an improvement upon earlier music in the Western world is still a matter of debate within the practice of music. It is possible that the extension of a practice may be seen by most within the practice (and those on the outside as well) as an important or even needed innovation, but it is equally possible that the practice will be divided about the innovation-as is the case with atonal music or the designated hitter in baseball, for example. Some may even see an "innovation" as a regression.

I do not think it is very helpful to think of practices as aiming at some perfected mode or product, even if some of those within practices do aim at such things (a perfect account of reality, for example, in physics). Rather, I would construe a practice or craft as a social phenomenon perhaps best described as a greenhouse or garden for human action. Like the controlled environments of a greenhouse or garden, practices limit and contain while at the same time encourage growth. Practices organize and impose standards upon human activity so that excellence may be realized. Without the containment of a practice, human action in a particular area would indeed enjoy more liberty but very likely less sophistication. Practices and crafts contain, restrain, and organize in
order to both control and allow for innovation.

Here, I would introduce Alfred North Whitehead's conception of style to flesh out the way in which practices validate both the containment and innovation of human action. Whitehead, in his famous Aims of Education, calls "style" the "ultimate morality of mind" and conceives of it as follows: 
It is an aesthetic sense, based on admiration for the direct attainment of a foreseen end, simply and without waste. Style in art, style in literature, style in science, style in logic, style in practical execution have fundamentally the same aesthetic qualities, namely attainment and restraint. The love of a subject in itself and for itself, where it is not the sleepy pleasure of pacing a mental quarter-deck, is the love of style as manifested in that study. ${ }^{3}$

Whitehead's understanding of style is very similar to Maclntyre's notion of being "inside a practice" or seeing the goods internal to a practice. It is an appreciation of the practice in and of itself. It is an appreciation of the standards of economy within the practice.

Style, I believe, is fundamentally related to the imaginative. Within the context of a practice, the imaginative is the twin of style where the dynamic of style is restraint and the dynamic of the imaginative is innovation. The two are, I believe, in a constant state of mediation within a practice. The drive for style, for precision and restraint, serves to ensure that the drive for the imaginative, the innovative, does not break apart the integrity of the practice. These two valuesthat of style and that of the imaginative-make it possible for a practice to simultaneously encourage both control and freedom. That which has style but no "imagination" is empty. That which is imaginative but without style is undisciplined.

The concept or label "imaginative" is a common nomative term. I am also suggesting that there is an important social function of our use of that term. The ecology of practices, of complex and rewarding activities such as mathematics, medicine, or baseball, shows forces both of containment and release. The breathing, if you will, of a practice is both inward and outward. I have proposed that the inward movement or force of a practice is determined by the value of style. The outward movement of a practice is determined by the value of the imaginative.

In a similar vein, Sharon Bailin argues for an understanding of creativity as significant achievement within traditions and not action that defies all tradition in irrational fits of inspiration. She writes:

[C]reativity has to do with significant achievement and such achievement takes place against the backdrop of dynamic and evolving traditions of knowledge and inquiry. It involves rule-following as well as rule-breaking and an understanding of when to do each. ${ }^{4}$

From such an understanding of the imaginative as a value internal to practices or crafts, we are ready to ask and answer the all-important question for education: what generates the imaginative? The imaginative is not a product of internal, mental processes but rather a feature of particular kinds of contextspecific competencies. To strive for the imaginative, one must have facility, perhaps even expertise, in a practice. One must have style, but a style tempered with a desire and ability to innovate.

Imaginative actions, wherever they are noticed, show a mixing of natural capacities and a readiness achieved through familiarity and submersion in many facets of the context-as well as, in some cases, an inclination on the part of the actor to push the boundaries or break the conventions of that context. Although we can never prepare students to produce imaginative work, we can prepare them for the attempt. The best preparation, it seems to me, involves watchfulness, alertness, and a taking-seriously of the practice in question as well as an 
understanding of the point of the practice. It would seem important to have mastered a practice, art, science, or physical activity to break its conventions or push its boundaries in a meaningful way. A craftsperson is unlikely to have his or her work evaluated as imaginative, inventive, or creative if it does not react to or against but simultaneously accommodate the tradition of the craft.

Seen this way, it will always be a bit silly to hand pencil and paper to students who have never had any contact with poetic form and convention and ask them to write imaginative poems. We continue to do such things, I think, because we still feel the effects of the Romantic imagination-we still believe that the exercise of the creative imagination alone produces the imaginative. While, in a sense, anything such students would generate would require inventiveness, it would not teach anyone much about the craft or art of poetry. To write imaginative poetry or paint imaginative paintings does not necessarily require formalized training (especially doctrinaire training), but it does seem to require an attentive commitment to doing poetry or doing painting. This commitment involves competencies and sensitivities to the medium of the craft, be it words, colours, or clay.

I would not, however, want to suggest that young children or those not fully initiated into practices or crafts cannot be imaginative or cannot demonstrate imaginative thought and action. The important criteria for the imaginative involves a recognition of how children (or anyone) has both incorporated the forms of a practice or discipline and also experimented with those forms. Thus, I am not arguing that we should devalue play or limit the ways in which children explore with materials or ideas. Rather, we should come to a more fully developed notion of what is important about imaginative, creative, and playful activity in young children and how standards and stylistic conventions factor into our understanding of imaginative play.

\section{Moving On}

If the separation of the imagination and the imaginative poses difficult educational problems, it also opens up new possibilities. One unfortunate byproduct of the attention given to the concept of imagination is that imaginative work is typically confined to the mind. Barrow offers the following criteria: "To be imaginative is to have the inclination and ability consciously to conceive of the unusual and effective in particular contexts." 5 However, analytic philosopher Alan R. White observes, "The exercise of one's imagination may take the form of sayings, writings, or doings." 6 Barrow's criteria for the proper use of "imaginative" is confined to the ability to "consciously conceive" in a certain way. Later he specifically states, "[imagination] can only be displayed in activities that involve thinking. For to have imagination means to conceptualize in a particular kind of way.",7

White's observation brings out two related problems in Barrow's conception of "to imagine" and his criteria for the imaginative, although these problems are certainly not confined to Barrow's thought. The problems, rather, are symptomatic of the Cartesian legacy of mind and body separation. The first problem involves Barrow's criterion of "consciously." The second is his "location" of imaginative work in thinking alone. Examples may help demonstrate the seriousness of these problems. White refers to a taxi driver who gets through rush-hour traffic as imaginative. ${ }^{8}$ Though a taxi driver may, 11(2), Winter) 1998 
indeed, be thinking in a particular way, we would probably tend to say that every choice (turn, brake, acceleration) is not a conscious and intentional activity in the way Barrow wants to emphasize. In fact, part of the effectiveness of a good rush-hour cabbie may lie in the fact that her responses are essentially "unconscious," that she does not, in effect, need to "think" to respond.

We seem to draw a peculiar, but very traditional line, in our common usage of the word "imaginative." This is hardly surprising given the mental focus of the imagination. Activity or work construed as primarily "mental" is described as imaginative more often than "physical" activity or work. We do not typically hear about "imaginative" athletes, though we do hear other normative labels-gifted, creative, and so on. On the border of this conceptual terrain lies activity such as improvisational music. We do use imaginative to describe jazz pianists and I do not think it is a simple misapplication of the word.

Such physical-mental distinction in our use of the word imaginative is unnecessary. We are forced into such distinctions when we attempt to conceptualize or define imaginative activity as being a product of certain steps or occurrences or the product of the imagination at-work. The mental focus also leads us to the problematic usage of words such as "conscious," "intentional," or "instinctive"--words which make sense as criteria only if we explain exactly how we are using them in each case. An imaginative brushstroke, musical phrase, or basketball manoeuvre may or may not happen in any recognizable planned, intentional manner. What makes the act imaginative is its quality-we did not think of painting, improvising, or moving in that way before and we are pleased to see a new way of thinking or doing the activity in question.

The imaginative jazz pianist must be ready to react "instinctively" to changing circumstances. This readiness springs from long hours of work coupled with talent. It comes from a thorough immersion in the forms of jazz music and a deep relationship with the capabilities of one's instrument and oneself. Imaginative musicians, athletes, scientists, or painters are good at what they do. They are good in a way that requires a special term-imaginative. Occasionally, the label imaginative is used to qualify the kind of goodness about a person or action. As a jazz listener myself, I know that there is much professional controversy about saxophonist John Coltrane's $A$ Love Supreme. Though critics debate the musical excellence, craftsmanship, and accessibility of the piece, no one would dare say that it is unimaginative.

We see then that Barrow is importantly right in one aspect of his criteria-no one is just suddenly imaginative outside of a context. Imaginative actions, wherever they are noticed, show a mixing of natural capacities and a state of readiness achieved through familiarity and submersion in many facets of the context. It would seem important to have mastered a practice, art, or science to push its boundaries. A craftsperson is unlikely to have his or her work evaluated as imaginative, inventive, or creative if it does not react to or against and accommodate the tradition of the craft.

Seeing imaginative "happenings" as products of a state of preparedness may open interesting lines of theoretical and practical inquiry. It broadens the focus to include physical and mental action and, perhaps, takes a step toward demolishing the borders between the two. It also may encourage educators to think about the concepts of craftsmanship and practice. If we continue to use 
the label imaginative as we usually do and continue to place value in it, it will always be a bit silly to hand pencil and paper to students who have never studied poetry and ask them to write imaginative poems. While, in a sense, anything such students would generate would require inventiveness, it would not teach anyone much about the craft of poetry.

\section{Conclusion}

Most arguments in favour of developing or exercising the imagination are arguments about curricular values or preferences masquerading as psychological or pseudo-psychological arguments. The psychological argument is that using or stimulating the imagination will strengthen or enhance it in some way. As we have seen, this argument does not make much sense.

The concept of imagination is very similar to the equally problematic concept of memory (indeed, the two are often closely connected). While we can employ strategies to memorize things more successfully and effectively, there is no reason to think that using our memory, whatever that may entail, makes it stronger. We may even become better at remembering certain kinds of things if we make a habit of employing strategies or if we live in a culture or society which requires the memorization of certain kinds of things. Yet, there is no good reason to assume that, if we do not make use of memorization strategies,
our memory is like an atrophied muscle.

Similarly, certain strategies or techniques may help us to imagine better (more vividly, in more detail, and so on) when called upon to do so, but we cannot say that these strategies build up, develop, or strengthen the faculty of imagination. When the psychological aspect of imagination arguments is taken away, we are left with arguments about what should belong in the curriculum. Egan, for example, believes that particular kinds of stories and a particular emphasis on story-creation should be one major vehicle for the curriculum. Warnock believes that the curriculum should avoid, at all costs, being boring. The imagination for her (and Coleridge) requires fare that invokes and marries our perceptive and emotional capacities. The menu in Warnock's school should be presented so that children have opportunities to create meaning for themselves, without the heavy hand of teacher authority telling them how they should create, interpret, or experience things.

These ideas may, of course, be good ones and probably are. But they cannot and should not be justified on the grounds that such approaches to the curriculum stimulate or develop the imagination. Rather, they should be justified as what they are: curricular arguments with moral, intellectual, and political ends. In essence, these arguments should be turned inside out. The vision of society that is implied by the curricular suggestions in Egan, Wamock, and many others should be brought out from behind the arguments about improving
the imagination.

At the beginning of this essay, I suggested that theorists interested in the imagination tend to be proponents of some kind of liberal education. What needs to be kept in the educational visions of these and similar thinkers is the connection between forms of liberal education and a liberated mind, even if we have some disagreements with the moral, intellectual, and political ends of the theorists. All these theorists, and this author himself, value imaginative work and want to see schools not only allowing but encouraging imaginative work. 
Deciding that conceptualizations of the imagination are, for the most part, deadend efforts does not leave us without a means by which to argue against dreary, uninspiring, or unimaginative educational practices. We can still make cases for the arts, for music, and storytelling by arguing that these disciplines, practices, and kinds of knowledge, and practices are important for our vision of society and are important occasions for imaginative work. We can argue that schools should be more hospitable to imaginative work, and that the curriculum and school schedule should provide more occasion for imaginative work (in all its forms), both for students and teachers.

\section{Notes}

${ }^{1}$ Concerning the dominance of the idea during the 18 th and early 19th centuries, James Engell argues: "Seldom in Western culture has one idea excited so many leading minds for such a stretch of time. It became the impelling force in artistic and intellectual life, in literature and philosophy, even in much political and social thought. especially from 1750 on." James Engell (1981), The Creative Imagination: Enlightenment to Romanticism (Cambridge, MA \& London, England: Harvard University Press), p. 4.

${ }^{2}$ Among the most widely read educational theorists whose work has involved the concept of the imagination are Kieran Egan and Maxine Greene. See, for example, Kieran Egan (1992), Imagination in Teaching and Learning: The Middle School Years (London, Ontario: The Althouse Press) and Maxine Greene (1995), "Art and Imagination," Phi Delta Kappan, 76(5), p. 378-382.

${ }^{3}$ There were, of course, many thinkers who discussed the imagination leading up to and during what is typically thought of as the "Romantic" period-a period with different starting and end dates in different parts of Europe.

${ }^{4}$ Engell, part I, chap. 1.

${ }^{5}$ Samuel Taylor Coleridge (1987) in Coleridge: Poems and Prose, Kathleen Raine (ed.) (Middlesex, England and New York: Penguin), p. 190. Selection from the Biographia Literaria.

${ }^{6}$ Engell, pp. 328-329.

${ }^{7}$ Though empathy and its connection to imagination has gained some attention recently. Especially of interest is Arne Johan Vetlesen (1994), Perception, Empathy, and Judgment: An Inquiry into the Preconditions of Moral Performance (University Park, PA: Pennsylvania State University Press).

${ }^{8}$ Robin Barrow (1988), "Some observations on the concept of the imagination" in Imagination and Education, K. Egan and D. Nadaner (eds.) (New York \& London: Teachers College Press), p. 79 and Gilbert Ryle, (1949) The Concept of Mind (London: Hutchinson).

${ }^{9}$ Barrow, p. 79.

10 Ryle, p. 245.

${ }^{11}$ Engell, p. 3-10.

${ }_{12}$ Mary Warnock (1976), Imagination (London: Faber), p. 153.

${ }^{13}$ Warnock, p. 201.

${ }^{14}$ Greene, p. 379.

${ }^{15}$ Mary Warnock (1977), Schools of Thought (London: Faber), p. 153. 
${ }^{16}$ See, for example, J.P. Isenberg and M.R. Jalongo (1993), Creative Expression and Play in the Early Childhood Curriculum (New York: Macmillan).

${ }^{17}$ Karen Hanson (1988), "Prospects for the good life: Education and perceptive imagination" in Kieran Egan and Dan Nadaner (Eds.), Imagination and Education (New York \& London: Teachers College Press), p. 129.

${ }^{18}$ Egan, 1992, p. 1.

${ }^{19}$ Egan, 1992, p. 65.

${ }^{20}$ Alan R. White sophisticates this exception with examples such as "imagine if Jane were angry." Though we can visualize facial expressions of someone who is angry, not only do we not need to do this to consider a situation in which someone were angry but it is impossible to directly visualize anger. See A.R. White (1990), The Language of Imagination (Oxford: Blackwell),

${ }^{21}$ Egan, p. 40 and J.P. Sartre (1968), The Psychology of Imagination, Bernard Frechtman (trans.) (New York: Washington Square Press, Inc.).

${ }^{22}$ White writes, "To imagine something is to think of it as possibly being so." White (1990), p. 184.

${ }^{23}$ It is important, however, to anticipate possible arguments posed by recent psychological and neurological research into the workings of the brain. It may indeed be the case that certain physical parts of our brain become more "active" than others when we are asked "to imagine" or "to believe." And though being able to respond to these kinds of questions certainly does require that we have a healthy brain, neither of these conditions substantiates a faculty view of the imagination. Until science reveals a road map of the brain so precise as to separate brain components into discrete compartments the logic of the faculty view cannot hold. My initial guess would be that the brain areas which become active when a person is asked "to imagine" something are those linked to the capacity for language.

${ }^{24}$ Northrup Frye (1963), The Educated Imagination (Toronto: Canadian Broadcasting Company), p. 140.

${ }^{25}$ Barrow, p. 81. Though I shall quibble later with Barrow's mental emphasis in his "'abstract representation," his description of the nature of the word
is on the mark.

${ }^{26}$ It may also appear to place one within the politically conservative chorus singing the praises of "standards." While I do not think that it is necessary to discuss what does and does not count as imaginative work, it would be a serious mistake to believe that any particular criterion is defensible. Just as

is "beautiful" we cannot grade with "imaginative" in mind.

University of Macintyre (1984), After Virtue (2nd edition) (Notre Dame, IN:

28 of Notre Dame Press), p. 191.

${ }^{29}$ Macintyre, 1984, p. 194.

30 MacIntyre, 1984, p. 194.

${ }^{31}$ Alfred North Whitehead (1949), The Aims of Education and Other Es-

says (New York: Mentor, New American Library), p. 24 .
32 Sharon Bailin (1988), Achieving Extraordinary Ends: An Essay on

Creativity (Boston: Kluwer), p 131. 
${ }^{33}$ Barrow, p. 84.

${ }^{34}$ White, p. 185.

${ }^{35}$ Barrow, p. 86.

${ }^{36}$ White, p. 186. 